\title{
Morphophysiology and ultrastructure of the male reproductive accessory glands of the bats Carollia perspicillata, Glossophaga soricina and Phyllostomus discolor (Chiroptera: Phyllostomidae)
}

\author{
Fabiane F. Martins ${ }^{a}$, Mateus R. Beguelini ${ }^{\mathrm{b}, *}{ }^{*}$, Cintia C.I. Puga ${ }^{\mathrm{c}}$, Eliana Morielle-Versute ${ }^{\mathrm{c}}$, \\ Patricia S.L. Vilamaior ${ }^{a}$, Sebastião R. Taboga ${ }^{a}$ \\ a Department of Biology, UNESP - Univ. Estadual Paulista, São José do Rio Preto, São Paulo, 15054-000, Brazil \\ ${ }^{\mathrm{b}}$ Center of Biological and Health Sciences, UFOB - Universidade Federal do Oeste da Bahia, Barreiras, Bahia, 47808-021, Brazil

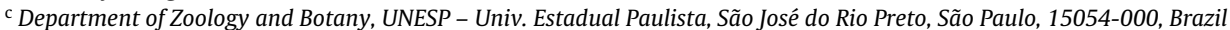

\section{A R T I C L E I N F O}

\section{Article history:}

Received 23 December 2015

Received in revised form 7 July 2016

Accepted 8 July 2016

\section{Keywords:}

Bulbourethral gland

Prostate

Reproduction

\begin{abstract}
A B S T R A C T
The male reproductive accessory glands (RAGs) are important organs that contribute to the secretion of different substances that composed the ejaculate. Despite this important function, their composition, anatomy and function vary widely between species. Thus, the RAGs of three species of phyllostomid bats were morphologically and ultrastructurally characterized and compared in this study. The RAGs of the three analyzed species are composed of a prostate and a pair of bulbourethral glands (BG). In all species, the prostate is composed of three well-defined regions (ventral, dorsolateral and dorsal regions). The ventral region showed an atypical epithelium (undefined) with no obvious cellular limits and a holocrine PAS-positive secretion. The dorsolateral region of Carollia perspicillata and Phyllostomus discolor showed a pseudostratified cubic morphology, and that from Glossophaga soricina had a columnar morphology endowed with cytoplasmic projections and stereocilia. The dorsal region of the three analyzed species is composed of a pseudostratified columnar epithelium endowed with stereocilia; however, G. soricina also presented cytoplasmic projections in the apical portions of the secretory cells similar to those in the dorsolateral region. The BG of the three analyzed species are composed of a pseudostratified columnar epithelium including basal and PAS-positive secretory cells. In conclusion, this study morphologically and ultrastructurally characterized the RAGs of three species of phyllostomid bats, demonstrating the presence of a novel third prostatic region in species of this family. The results also showed the absence of seminal vesicles and ampullary glands, and better characterized the holocrine pattern of the prostatic ventral region, which is unique to bats.
\end{abstract}

(ㄷ) 2016 Elsevier GmbH. All rights reserved.

\section{Introduction}

The male reproductive accessory glands (RAGs) are important organs that contribute to the secretion of different substances that composed the ejaculate (Krutzsch et al., 1976; Mokkapati and Dominic, 1976). According to Stevens and Lowe (2001), the seminal vesicles produce a secretion rich in prostaglandins, proteins, amino acids and fructose, which are the main nutrients of spermatozoa. The bulbourethral glands have a small diameter and secrete a mucoid fluid, which is rich in sugars, including galactose, whose function is related to lubrication. Moreover, the prostate is a funda-

* Corresponding author at: José Seabra de Lemos n ${ }^{\circ}$ 316, Recanto dos Pássaros, Barreiras, Bahia 47808-021, Brazil.

E-mail address: mateus.beguelini@ufob.edu.br (M.R. Beguelini). mental RAG of the male reproductive tract that produces different secretions that promote the survival, viability and motility of spermatozoa (Rochel et al., 2007). It is a gland comprised of secretory acini, which are surrounded by connective tissue (stroma) and ducts that open directly into the urethra.

These glands (prostate, seminal vesicles, bulbourethral and ampullary glands, etc.) showed great plasticity in composition, morphology and distribution in mammals, which varied according to the study group. In rodents, the prostate gland has four distinct lobes surrounding the urethra, located at the base of the urinary bladder. These include the ventral, lateral and dorsal lobes and the seminal vesicle, which is connected to the anterior lobe and is also called the coagulating gland (Price, 1963; Jesik et al., 1982). The RAGs of the Mongolian gerbil exhibit the same characteris- 
tics described for the other rodents, however, they also contain a dorsolateral lobe (Rochel et al., 2007).

In humans and dogs, the prostate does not show a multilobed pattern of organization, consisting of closely related areas that form a compact structure associated with the seminal vesicle and bulbourethral glands (Price, 1963; McNeal, 1981, 1983).

In the last decades, evidence shows that the RAGs of bats are also highly variable, with this variation occurring between different families, subfamilies and sometimes interspecifically (Krutzsch, 1976; Crichton and Krutzsch, 2000; Krutzsch and Nellis, 2006; Puga et al., 2013, 2014; Negrin et al., 2014; Christante et al., 2015; Beguelini et al., 2015; Martins et al., 2015). Studies in the Phyllostomidae family have shown a pattern of compression of the prostate complex, which is divided into two (ventral and dorsal) or three regions (ventral, dorsolateral and dorsal). This pattern is similar to that observed in the Noctilionidae and Emballonuridae families (Beguelini et al., 2016).

On the other hand, the Molossidae family showed a semi-lobed pattern of the prostate complex, which consisted of a unique and large ventral region and a tetralobed dorsal region (Christante et al., 2015). Meanwhile, the Vespertilionidae family presented a multilobular pattern of the prostate complex (Negrin et al., 2014), composed of three bilobed regions (ventral, dorsolateral and dorsal). It is interesting to note that in all the analyzed bat species, the prostate complex was accompanied by paraurethral and bulbourethral glands, with the absence of seminal vesicles and ampullary glands.

Based on these variations, the aim of this study was to characterize and compare the morphology and ultrastructure of the RAGs of the bats Carollia perspicillata (Carollinae), Glossophaga soricina (Glossophaginae) and Phyllostomus discolor (Phyllostominae).

Studies show that $C$. perspicillata has a seasonal polyestrous pattern of reproduction with two reproductive periods, the greatest in June-August and a second in February-May (Willig, 1985; Williams, 1986; Cloutier and Thomas, 1992). Moreover, G. soricina shows an aseasonal polyestrous pattern in some locations or a bimodal polyestrous pattern in others (Willig, 1985; Alvarez et al., 1991); and P. discolor, despite having a seasonal polyestrous pattern of reproduction, has the periods of mating, pregnancy, and birth varying geographically (Krutzsch, 2000; Kwiecinski, 2006).

\section{Materials and methods}

\subsection{Study area, capture and licenses}

Bats were collected in northwest of São Paulo State, Brazil (city of São José do Rio Preto - 49 $22^{\prime} 45^{\prime \prime} \mathrm{W} 20^{\circ} 49^{\prime} 11^{\prime \prime}$ S), between August 2010 and July 2012. The captures were performed at night using five mist nets $(3 \times 6 \mathrm{~m})$, which were precisely set on possible flight paths or at exits from shelters.

The Brazilian Institute of Environment (Instituto Brasileiro do Meio Ambiente, IBAMA - Processes: 21707-1) authorized the capture and captivity of bats, and the ethics committee (CEEA-UNESP, São Paulo State University - Process: 017/2009) authorized all experimental procedures.

Following their capture, the bats were kept in individual cages $(40 \times 20 \times 20 \mathrm{~cm})$ with water ad libitum, in a specific room in darkness at $25-30^{\circ} \mathrm{C}$, until the following morning, when they were sacrificed and processed.

\subsection{Species, aging and experiment}

The species analyzed were the exclusively Neotropical bats, Carollia perspicillata (Carollinae), Glossophaga soricina (Glossophaginae) and Phyllostomus discolor (Phyllostominae). The International
Union for Conservation of Nature (IUCN) Red List of Threatened Species do not list these species as endangered.

Six sexually mature males of $C$. perspicillata and $G$. soricina and three of $P$. discolor were used in the study. The bats were collected at different months.

The differentiation between adults and youth was made based on the body weight, wear of the teeth, degree of ossification of the metacarpal-phalangeal epiphyses, (De Knegt et al., 2005) and the occurrence of sperm within the testes, epididymis and/or prostatic urethra (Beguelini et al., 2013a,b; Beguelini et al., 2014a,b; Puga et al., 2014).

\subsection{Processing of animals and analyses}

Bats were euthanized by deep anesthesia, which consisted of a mixture of ketamine $(370 \mathrm{mg} / \mathrm{kg}$; Dopalen-Vertebrands, Paulínia, SP, Brazil) and xylazine $(16 \mathrm{mg} / \mathrm{kg}$; Rompun-Bayer S.A., São Paulo, SP, Brazil) applied in an amount of $0.1 \mathrm{ml}$ per $50 \mathrm{~g}$ of body weight ( $0.08 \mathrm{ml}$ ketamine plus $0.02 \mathrm{ml}$ of xylazine). After confirming the death, the specimens were accommodated in a supine position on the dissection board, an incision was made in the abdomen, and the RAGs were removed and subjected to histological and ultrastructural analyses.

The specimens are housed and stored in the São Paulo State University, at the Chiroptera collection (DZSJRP- UNESP).

\subsection{Histochemistry}

The organs were fixed by immersion in Karnovsky's fixative solution (0.1 M Sørensen's phosphate buffer, $\mathrm{pH} 7.2$, containing $5 \%$ paraformaldehyde and $2.5 \%$ glutaraldehyde) for at least $24 \mathrm{~h}$. The tissues were dehydrated with ethanol, embedded in glycol methacrylate (Historesin, Leica Microsystems, Nussloch, Germany) and sectioned ( $3-\mu \mathrm{m}$ thick slices). Tissue sections were stained with hematoxylin-eosin (Ribeiro and Lima, 2000), toluidine blue (Mello and Vidal, 1980), periodic acid-Schiff (PAS; Behmer et al., 1976) and Gömöri's reticulin stain (Gömöri, 1937). Microscopic analyses were performed using an Olympus BX60 microscope (Olympus Optical, Tokyo, Japan) coupled with the Image-Pro-Plus for Windows software (Media Cybernetics, Rockville, USA) for image analysis.

\subsection{Transmission electron microscopy}

Each region of the RAGs was isolated, cut into small pieces $(1 \mathrm{~mm})$, perforated and fixed by immersion in a solution of $3 \%$ glutaraldehyde plus $0.25 \%$ tannic acid in Millonig buffer $(\mathrm{pH} 7.3$; $0.844 \mathrm{~g}$ of $\mathrm{NaH}_{2} \mathrm{PO}_{4}+0.193 \mathrm{~g} \mathrm{NaOH}+0.270 \mathrm{~g}$ glucose $+50 \mathrm{ml}$ distilled water) containing $0.54 \%$ glucose for $24 \mathrm{~h}$ at $4{ }^{\circ} \mathrm{C}$. After washing with Millonig buffer, the samples were post-fixed with $1 \%$ osmium tetroxide for $2 \mathrm{~h}$, dehydrated in acetone and embedded in Araldite 502 Resin (Electron Microscopy Sciences, Hatfield, PA, USA). Ultrathin sections $(50 \mathrm{~nm})$ were made using diamond knives, stained with $2 \%$ uranyl acetate for 30 min followed by $2 \%$ lead citrate in sodium hydroxide for $10 \mathrm{~min}$ and analyzed on a transmission electron microscope (Model 906; Leo-Zeiss, Cambridge, UK) at the Laboratory of Microscopy and Microanalysis "Prof. Dr. Celso Abbade Mourão" (IBILCE-UNESP).

\section{Results}

\subsection{Histology and histochemistry}

The presence of three prostatic regions (ventral, dorsolateral and dorsal) previously postulated by Martins et al. (2015) was confirmed by histological analysis of the three analyzed species $-C$. perspicillata, G. soricina and P. discolor. 


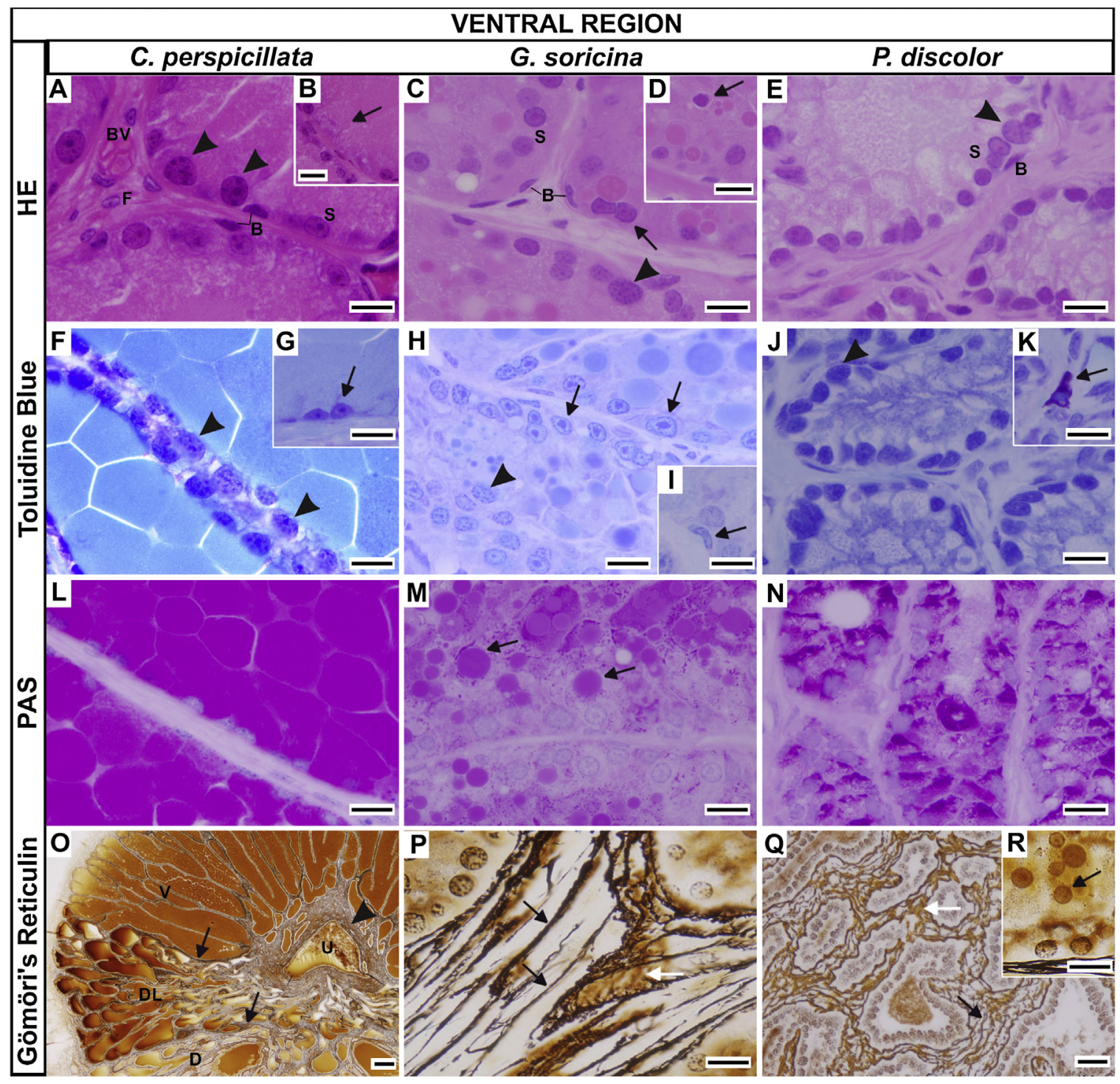

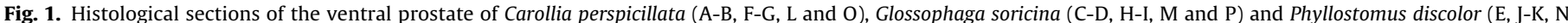

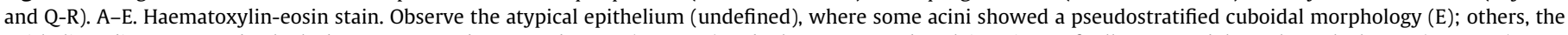

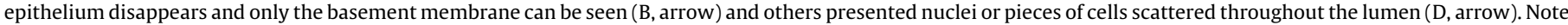

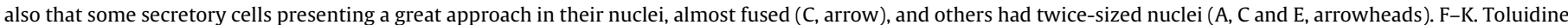

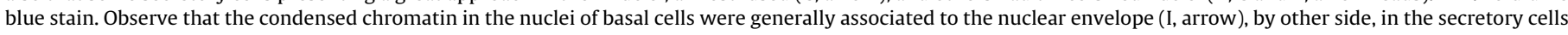

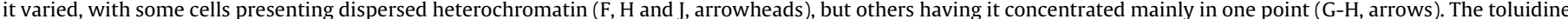

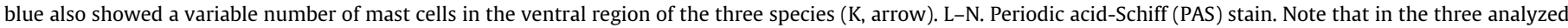

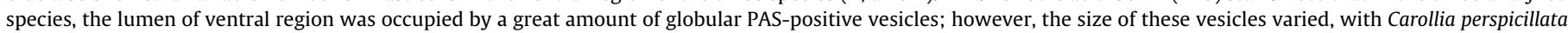

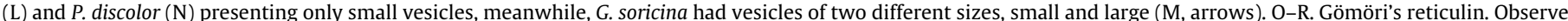

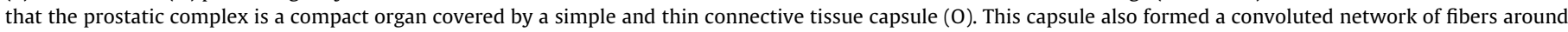

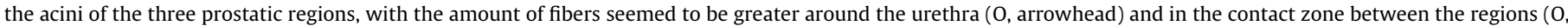

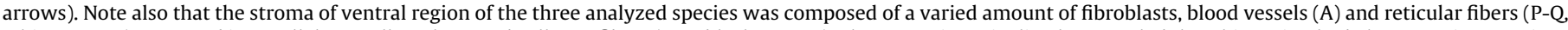

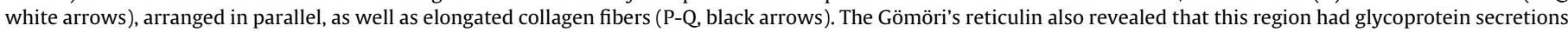
(R, arrow). (B, basal cell; BV, blood vessel; D, dorsal region; DL, dorsolateral region; F, fibroblast; S, secretory cell; U, urethra; V, ventral region). Scale bars = $10 \mu \mathrm{m}$.

The ventral region had similar characteristics in the three analyzed species including an atypical epithelium (undefined) with no obvious cellular limits (Fig. 1A and C). Some acini showed a pseudostratified cuboidal morphology (Fig. 1E), while in other acini, the epithelium was absent and only the basement membrane was visible (Fig. 1B), and yet other acini presented nuclei or cellular fragments scattered throughout the lumen (Fig. 1D). Together, these histological features characterize a holocrine secretion pattern. However, both basal and secretory cell types were present within the epithelium. The basal cells were thin with elongated nuclei and were firmly adhered to the basal lamina (Fig. 1A, C and E). The secretory cells had a larger cytoplasmic area containing a variable number of secretory vesicles. The nuclei of secretory cells were generally basal, with some cells presenting nuclei that were almost fused (Fig. 1C) and others containing nuclei that were twice as large (Fig. $1 \mathrm{~A}, \mathrm{C}$ and $\mathrm{E}$ ).

In the three analyzed species, there was a similar amount of heterochromatin in the basal cell nuclei, which was usually associated with the nuclear envelope (Fig. 1I). However, the heterochromatin in some secretory cells was either dispersed throughout the nucleus (Fig. 1F, H and J) or had a more concentrated distribution (Fig. 1G-H).

Toluidine blue staining also showed a variable number of mast cells in the ventral region of the RAGs of $C$. perspicillata, $G$. soricina and $P$. discolor (Fig. 1K). 


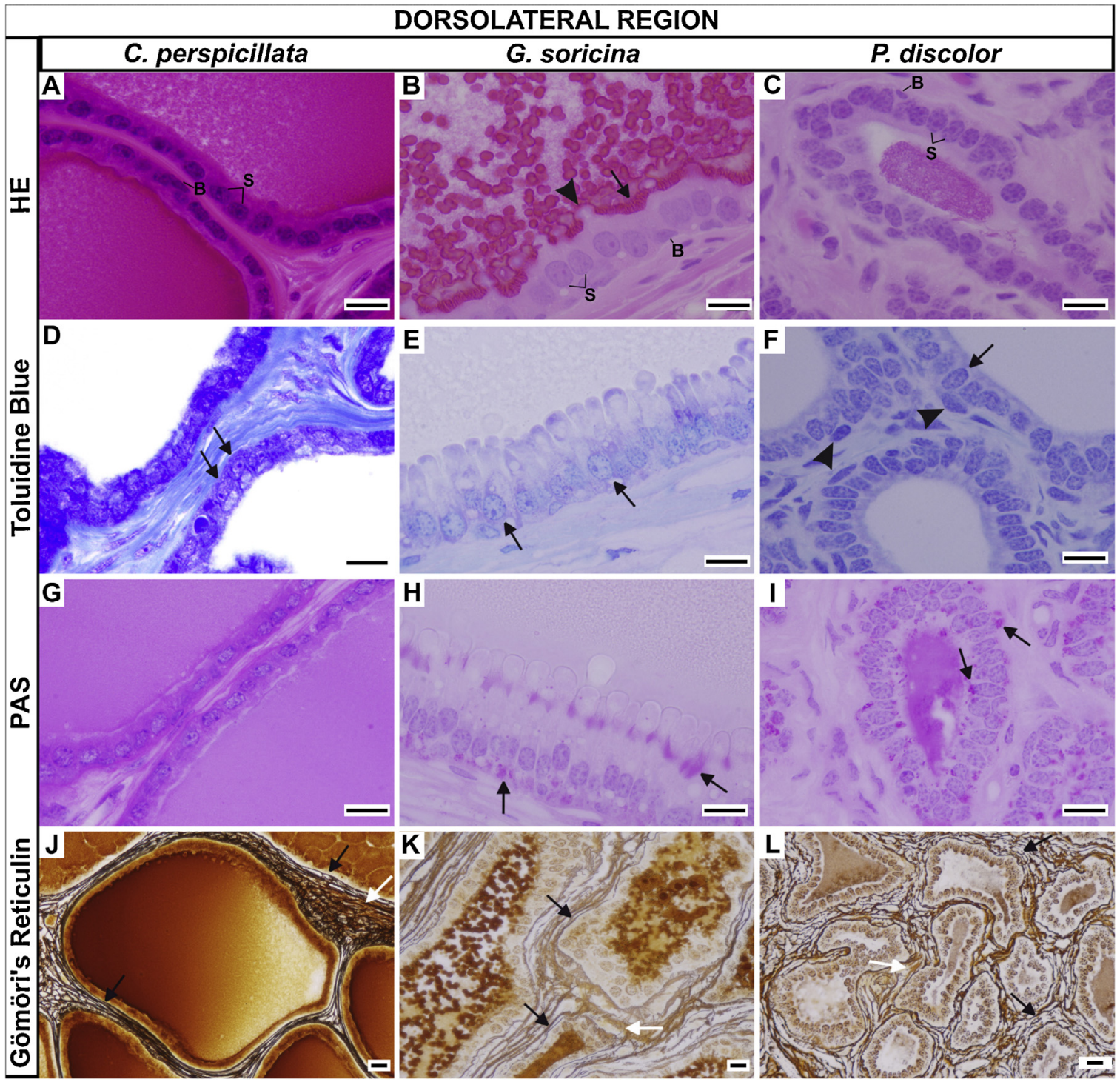

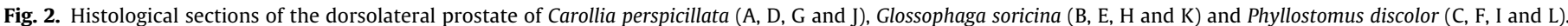

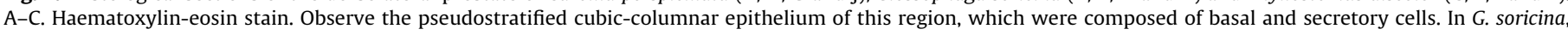

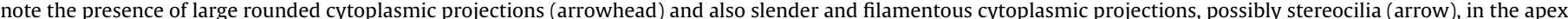

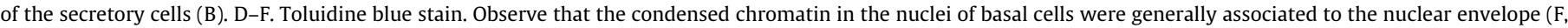

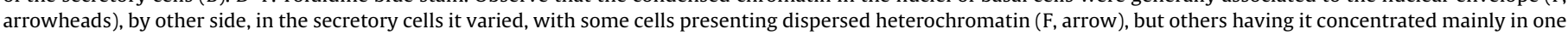

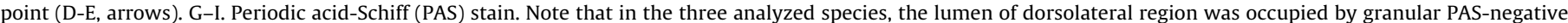

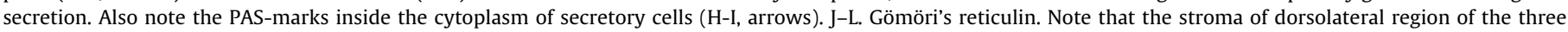

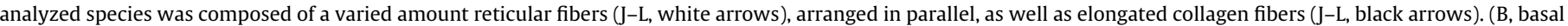
cell; S, secretory cell). Scale bars $=10 \mu \mathrm{m}$.

In the three analyzed bat species, the lumen of the ventral region was occupied by a significant number of globular PAS-positive vesicles (Fig. 1L-N); however, the size of these vesicles varied. Carollia perspicillata (Fig. 1L) and P. discolor (Fig. 1N) both had small vesicles in the lumen and inside the cytoplasm of secretory cells in the ventral region; whereas, $G$. soricina had both small and large vesicles (Fig. 1M).

Analysis of RAGs by Gömöri's reticulin staining in the three analyzed species showed that the prostatic complex is a compact organ covered by a simple and thin connective tissue capsule (Fig. 10). This capsule was composed mainly of reticular and collagen fibers, which also formed a convoluted network of fibers in the extracellular matrix around the acini of the three prostatic regions. The fibers appeared to be concentrated around the urethra and in the contact zone between the regions (Fig. 10); however, some portions inside each region were also very fibrous.
The stroma of the ventral region of the three analyzed species was composed of a variable amount of fibroblasts, blood vessels (Fig. 1A) and reticular fibers, arranged in parallel, as well as elongated collagen fibers (Fig. 1P-Q). Gömöri's reticulin staining also revealed that this region contained glycoprotein secretions (Fig. 1R).

The dorsolateral region of the three analyzed species was composed of acini with sinuous contours consisting of a pseudostratified cubic-columnar epithelium, containing both basal and secretory cells (Fig. 2A-C). The basal cells were scattered throughout the epithelium but firmly adhered to the basal lamina, and they contained elongated nuclei and little cytoplasm that did not extend to the lumen (Fig. 2A-C). In contrast, the secretory cells were cubic-columnar shaped with round and basally located nuclei and cytoplasm that extended from the basal lamina to the lumen of the acini (Fig. 2A-C). In G. soricina, the secretory cells also pre- 


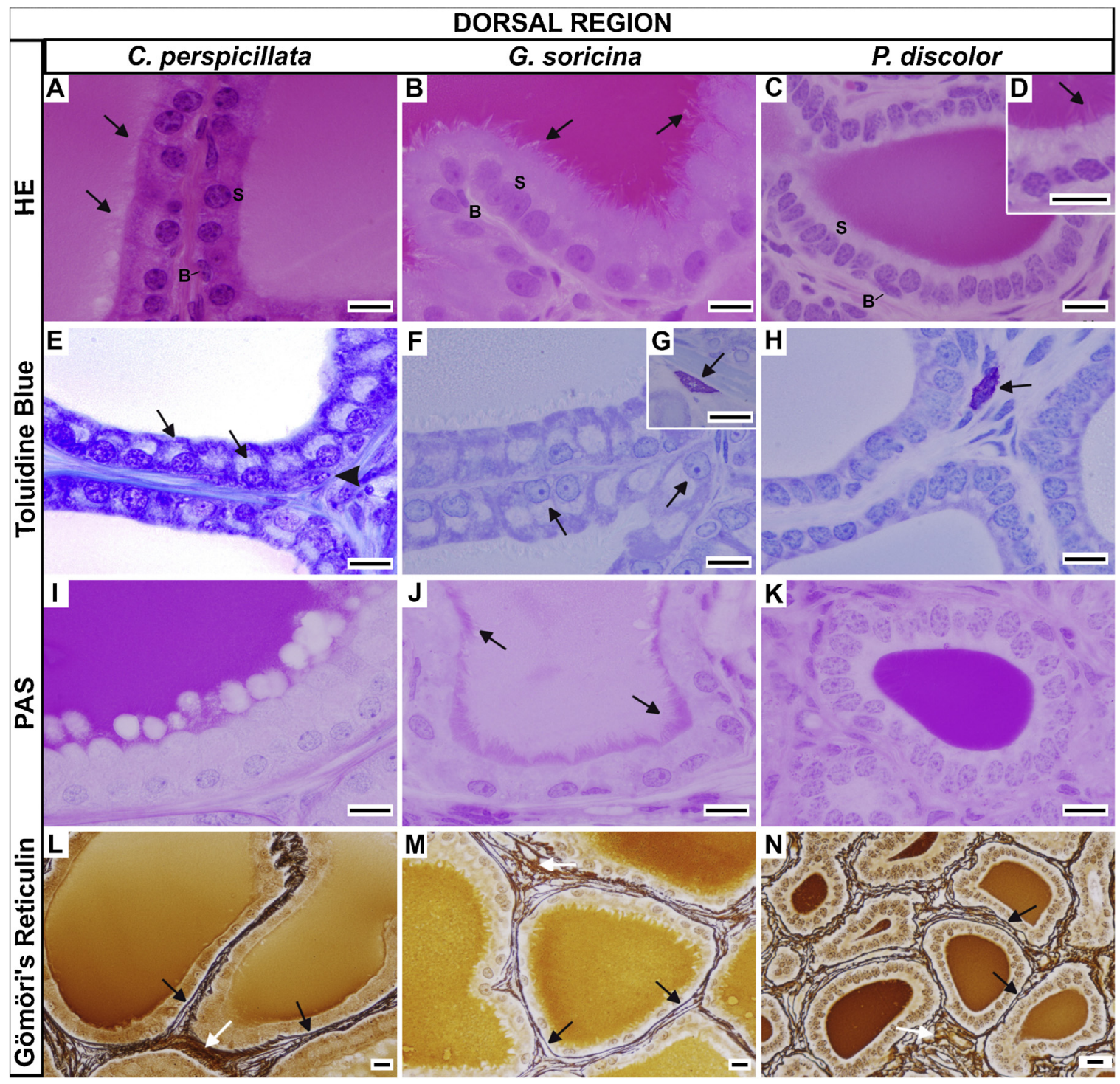

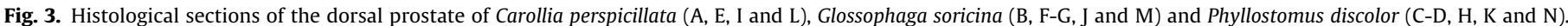

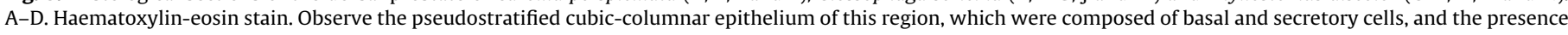

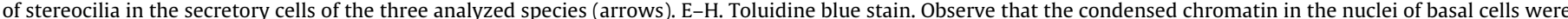

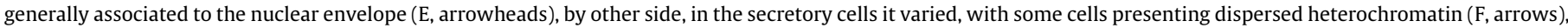

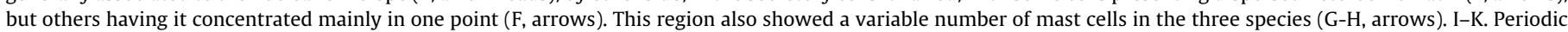

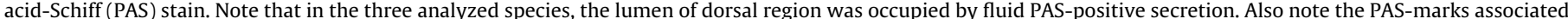

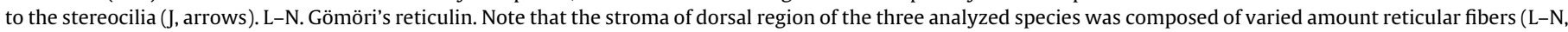
white arrows), arranged in parallel, as well as elongated collagen fibers ( $\mathrm{L}-\mathrm{N}$, black arrows). (B, basal cell; $\mathrm{S}$, secretory cell). Scale bars $=10 \mu \mathrm{m}$.

sented large rounded cytoplasmic projections into the lumen of the acini and slender, filamentous cytoplasmic projections that may be stereocilia (Fig. 2B).

In the three analyzed species, the basal cell nuclei contained condensed chromatin that was generally associated with the nuclear envelope (Fig. 2F). However, the heterochromatin was dispersed in some secretory cell nuclei (Fig. 2F), while in others it was concentrated in one region (Fig. 2D-E). The lumen of this region was occupied by a granular PAS-negative secretion (Fig. 2G-I), and the stroma was composed of a variable amount of reticular fibers arranged in parallel, as well as elongated collagen fibers (Fig. 2J-L).

The dorsal region of the three analyzed species also contained acini with a pseudostratified cubic-columnar epithelium composed of basal and secretory cells (Fig. 3A-C). The basal cells were scattered throughout the epithelium and were firmly adhered to the basal lamina; they had elongated nuclei and little cytoplasm that did not extend to the lumen (Fig. 3A-C). The secretory cells were cubic-columnar shaped with cytoplasm extending from the basal lamina to the lumen of the acini, and they contained round and basally located nuclei (Fig. 3A-C). However, the three species presented secretory cells with filamentous cytoplasmic projections, which may be stereocilia (Fig. 3A-D).

In the three analyzed species, the basal cell nuclei contained condensed chromatin generally associated with the nuclear envelope (Fig. 3F). However, the heterochromatin in the secretory cells was either dispersed (Fig. $3 \mathrm{~F}$ and $\mathrm{H}$ ) or concentrated in one particular region (Fig. $3 \mathrm{~F}$ ). The dorsal region also showed a variable number of mast cells in the three species (Fig. 3G-H). The lumen of this region was occupied by a fluid PAS-positive secretion (Fig. 3I-K), and the stroma was composed of a variable amount of reticular fibers, arranged in parallel, as well as elongated collagen fibers (Fig. 3L-N).

The bulbourethral glands of the three analyzed species contained acini with pseudostratified cubic-columnar epithelia, 


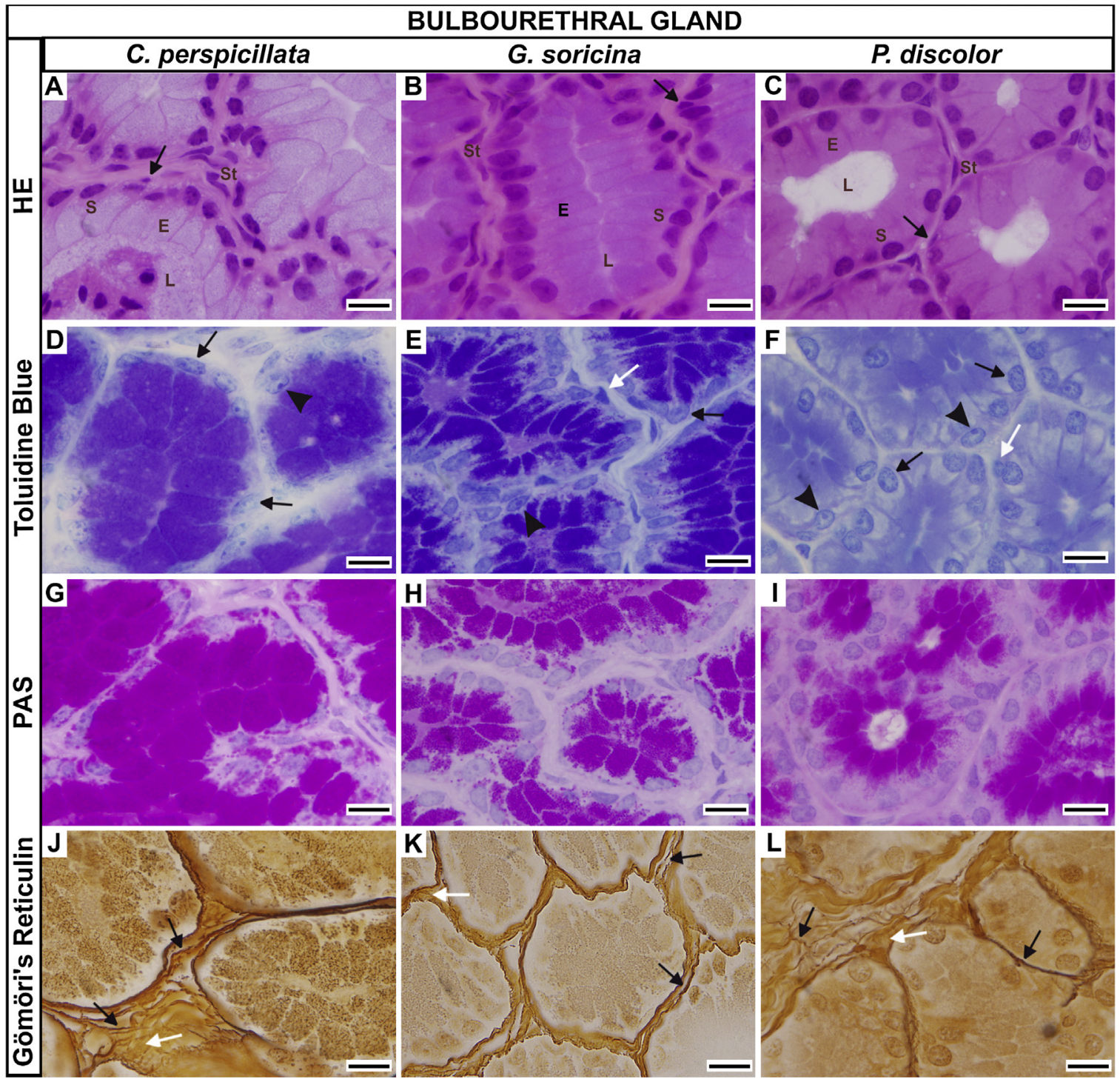

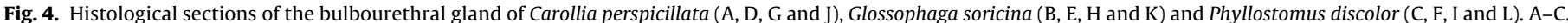

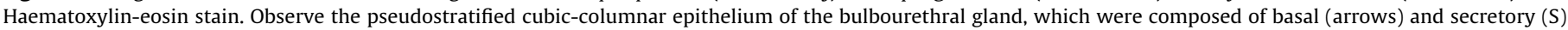

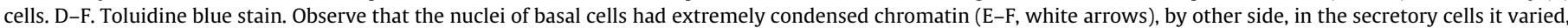

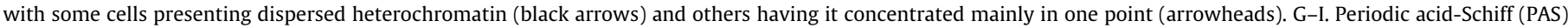

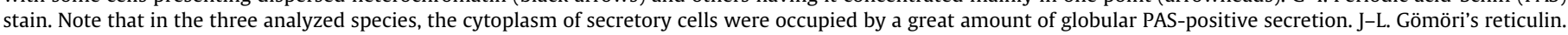

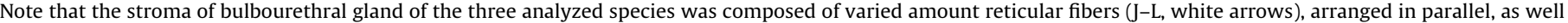
as elongated collagen fibers (J-L, black arrows). (E, epithelium; L, lumen; S, secretory cell; St, stroma). Scale bars $=10 \mu \mathrm{m}$.

composed of basal and secretory cells (Fig. 4A-C). The few basal cells present were scattered throughout the epithelium and firmly adhered to the basal lamina. They had elongated nuclei and little cytoplasm that did not extend to the lumen (Fig. 4A-C). The secretory cells were cubic-columnar shaped containing round and basally located nuclei with cytoplasm extending from the basal lamina to the lumen of the acini (Fig. 4A-C).

In the three analyzed species, the basal cell nuclei contained extremely condensed chromatin (Fig. 4E). However, the heterochromatin was either dispersed (Fig. 4D-F) or concentrated in a particular area in the secretory cells (Fig. 4D-F). The cytoplasm of the secretory cells was occupied by a significant amount of globular PAS-positive secretion (Fig. 4G-I). The stroma was composed of a variable amount of reticular fibers, arranged in parallel, as well as elongated collagen fibers (Fig. 4J-L).

\subsection{TEM evaluation}

Morphological analyses by TEM confirmed that the epithelium was undefined in the ventral region in the three analyzed species (Fig. 5). This epithelium varied from a pseudostratified cuboidal morphology (Fig. 5J) to acini devoid of cells at certain points and only a remaining basement membrane (Fig. 5A). Ultrastructural analysis revealed the loss of adherence of some secretory cells to the basal lamina (Fig. 5B), as well as cellular fragments scattered through the lumen of the acini (Fig. 5A). Nevertheless, the basal and secretory cells comprised the two distinct cell types present in the epithelium (Fig. 5C and J).

The basal cells were firmly adhered to the basal lamina and showed more electron density by TEM analysis (Fig. 5C, G, J and M). The basal cell nuclei were elongated and occupied almost the entire cytoplasm, and the condensed chromatin was associated with the nuclear envelope at various points (Fig. 5C, G, J and M). Secretory 


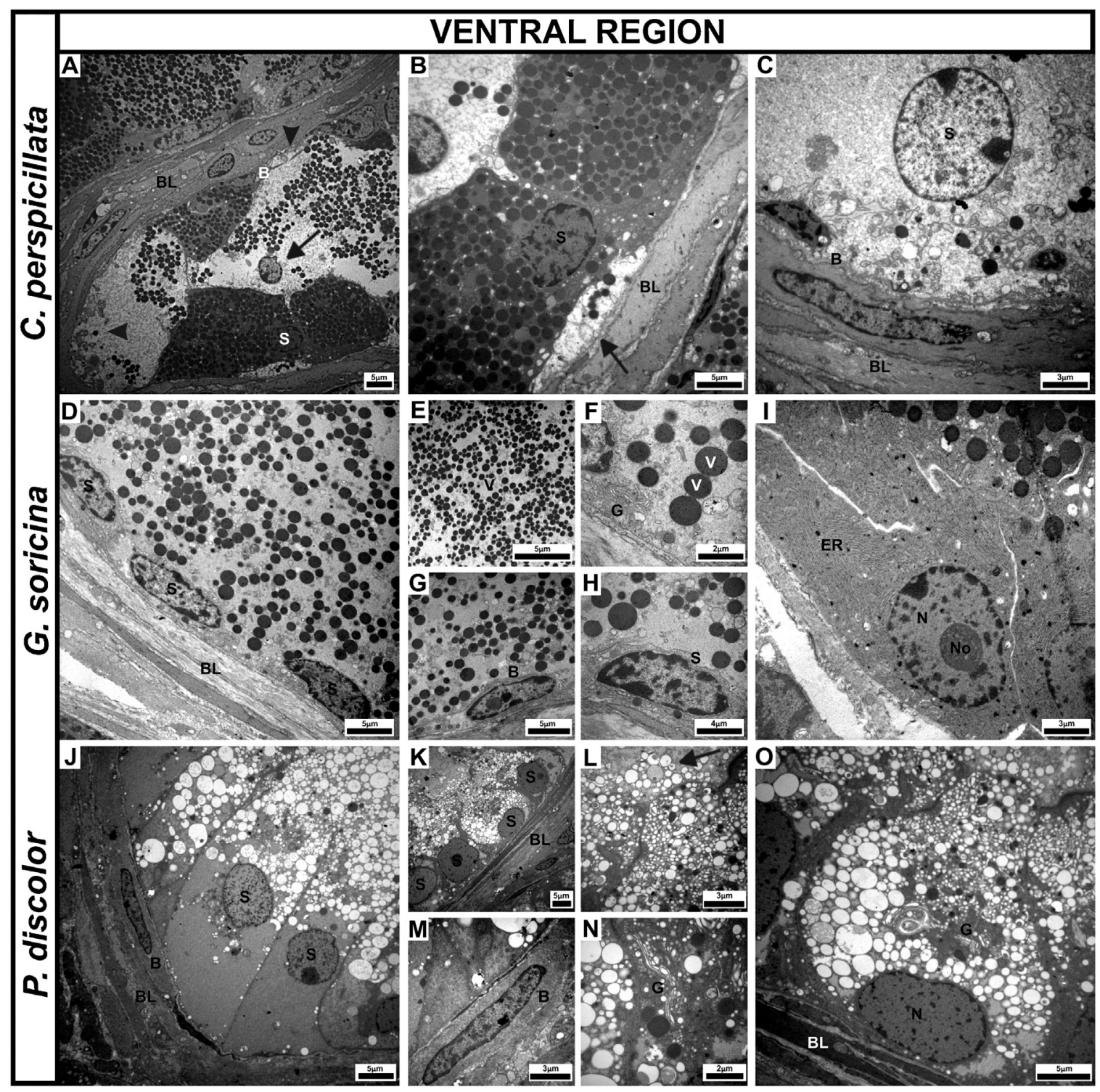

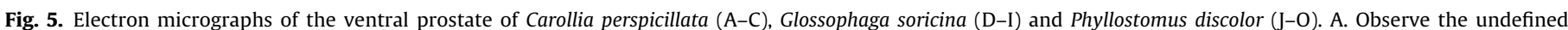

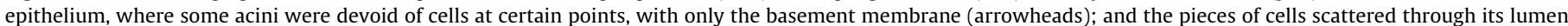

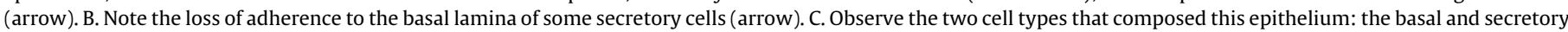

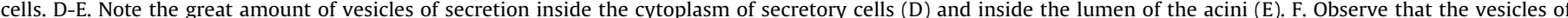

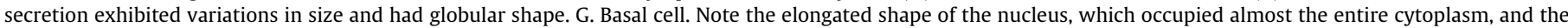

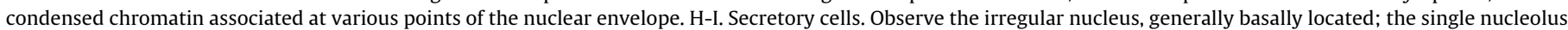

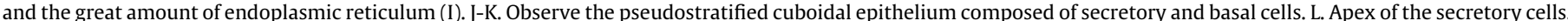

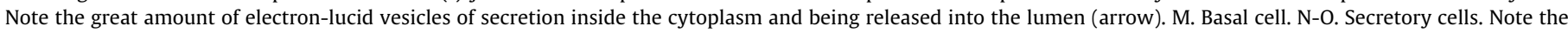

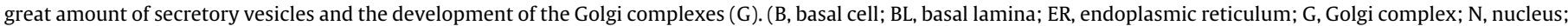
No, nucleolus; S, secretory cell; $\mathrm{V}$, secretory vesicles).

cells that were in contact with the basal lamina or associated with the basal cells were larger, and the apical surface of their plasma membrane touched the lumen of the acini (Fig. 5B, D, J and O). The nuclei were spherical (Fig. 5C and J-K) or irregular in morphology (Fig. 5H-I and O), generally basally located and contained only one nucleolus (Fig. 5I). The condensed chromatin was associated with the nuclear envelope primarily at two points (Fig. 5C). The cytoplasm of these cells was large and populated by a significant amount of endoplasmic reticulum (Fig. 5I), Golgi complexes (Fig. 5F and $\mathrm{N}$ ) and numerous globular-shaped secretory vesicles of various sizes (Fig. 5A-B, D, F-H, J-L and N-O).

Despite these ultrastructural similarities, the three species also showed some differences in subcellular characteristics. For example, C. perspicillata presented two types of secretory cells, one dark and other white in appearance. The dark secretory cells were electron-dense cells with a large number of stored secretory vesicles within the cytoplasm (Fig. 5B), while the white secretory cells were electron-lucid cells that contained a small number of cytoplasmic secretory vesicles (Fig. 5C). However, G. soricina and $P$. discolor showed no such differentiation. An additional difference is that the secretory vesicles of $C$. perspicillata (Fig. 5A-B) and G. soricina (Fig. 5D-I) were highly electron-dense structures, while those of $P$. discolor were electron-lucid (Fig. 5J-O).

The analyses showed that the epithelium of the dorsolateral region had a pseudostratified cubic morphology in $C$. perspicillata (Fig. 6A-C) and P. discolor (Fig. 6J-M), but a columnar morphology in G. soricina (Fig. 6D-I). However, the epithelium of the dorsolat- 


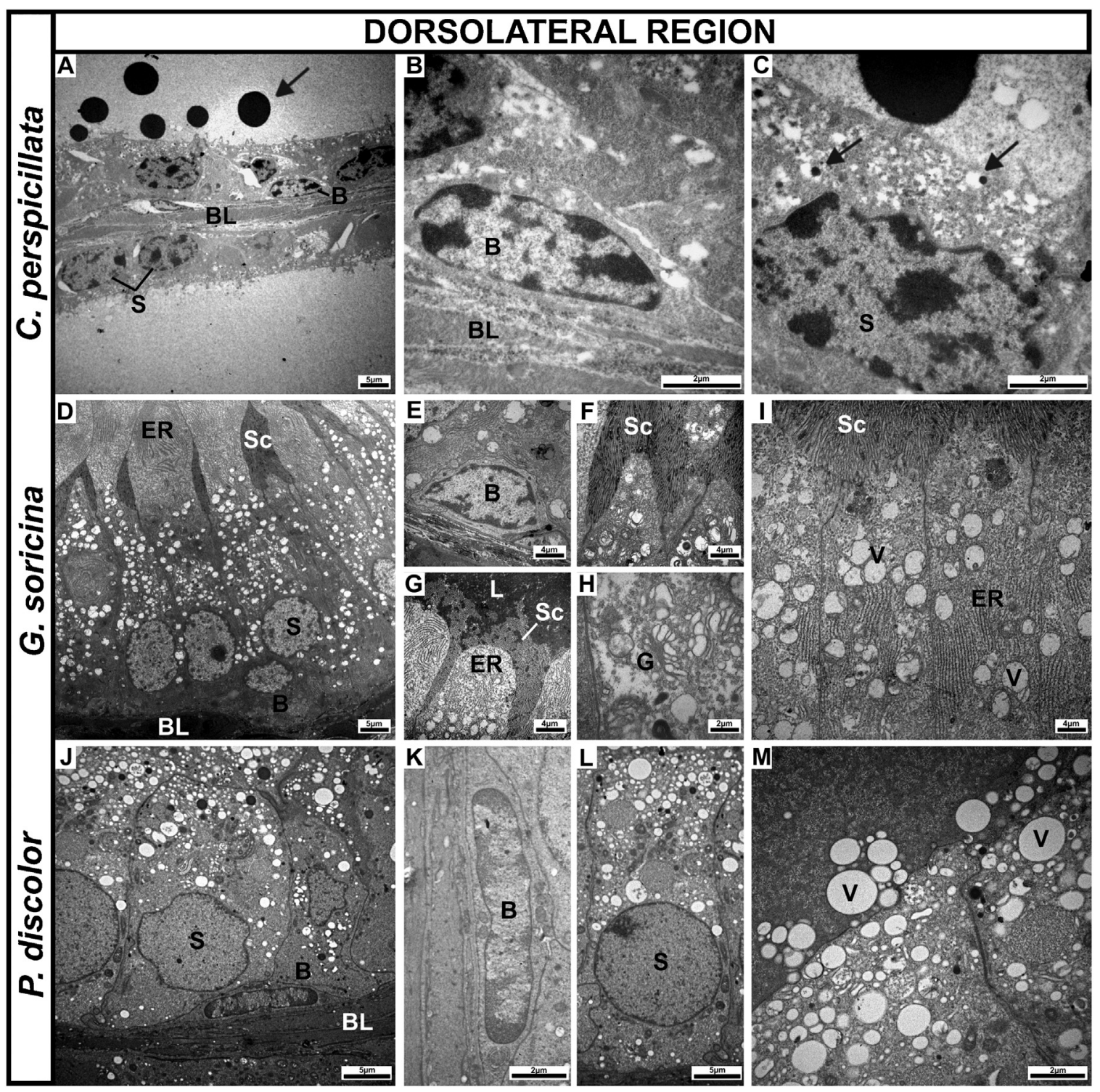

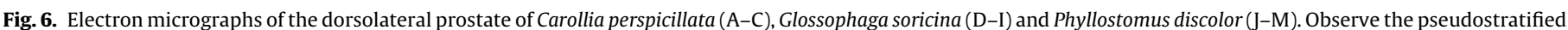

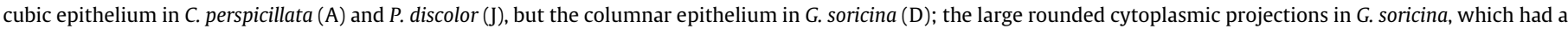

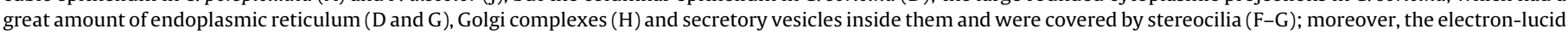

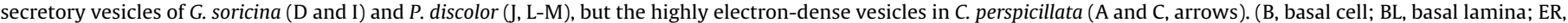
endoplasmic reticulum; G, Golgi complex; L, lumen; S, secretory cell; Sc, stereocilia; V, secretory vesicles).

eral region in all species was consistently composed of two distinct cell types: the basal and secretory cells (Fig. 6A, D and J).

Unlike the ventral region, the basal cells of the dorsolateral region presented a less compact and more electron-lucid morphology (Fig. 6B, E and K). They were firmly adhered to the basal lamina; their nuclei were elongated and contained condensed chromatin, which was associated with the nuclear envelope at various points (Fig. 6B, E and K). The secretory cells had a cubic morphology in $C$. perspicillata (Fig. 6A and C) and P. discolor (Fig. 6J and L), however, they were columnar cells with of large, rounded cytoplasmic projections and stereocilia in G. soricina (Fig. 6D-I). The cytoplasmic projections were composed of a significant amount of endoplasmic reticulum (Fig. 6D and G), Golgi complexes (Fig. 6H) and secretory vesicles and were covered by stereocilia (Fig. 6F-G).

In this region, the secretory vesicles of $G$. soricina (Fig. 6D and I) and $P$. discolor (Fig. 6J, L-M) were electron-lucid, while those in $C$. perspicillata (Fig. 6A and C) were highly electron-dense structures.
In the three analyzed species, the dorsal region showed a pseudostratified columnar epithelium endowed with stereocilia (Fig. 7), which was composed of the basal and secretory cells. The basal cells presented a less compact and more electron-lucid morphology similar to those in the dorsolateral region; however, the condensed chromatin in their nuclei was associated with the nuclear envelope at various points (Fig. 7A, C, G-H and M-N). The secretory cells were large, populated by a significant amount of endoplasmic reticulum (Fig. 7F and P-R), Golgi complexes (Fig. 7E-F, K and Q-R) and numerous secretory vesicles (Fig. 7F, $\mathrm{K}$ and $\mathrm{R}$ ) and endowed with stereocilia (Fig. 7D, F, I-M and O).

In this region, the secretory cells of $G$. soricina also presented cytoplasmic projections (Fig. 7L) and there were many mast cells in the stroma of all analyzed species (Fig. 7B).

The ultrastructural analysis showed that the epithelium of the bulbourethral gland of the three analyzed species was pseudostratified columnar and composed of basal and secretory cells (Fig. 8). The basal cells were scarce and firmly adhered to the basal lamina, 


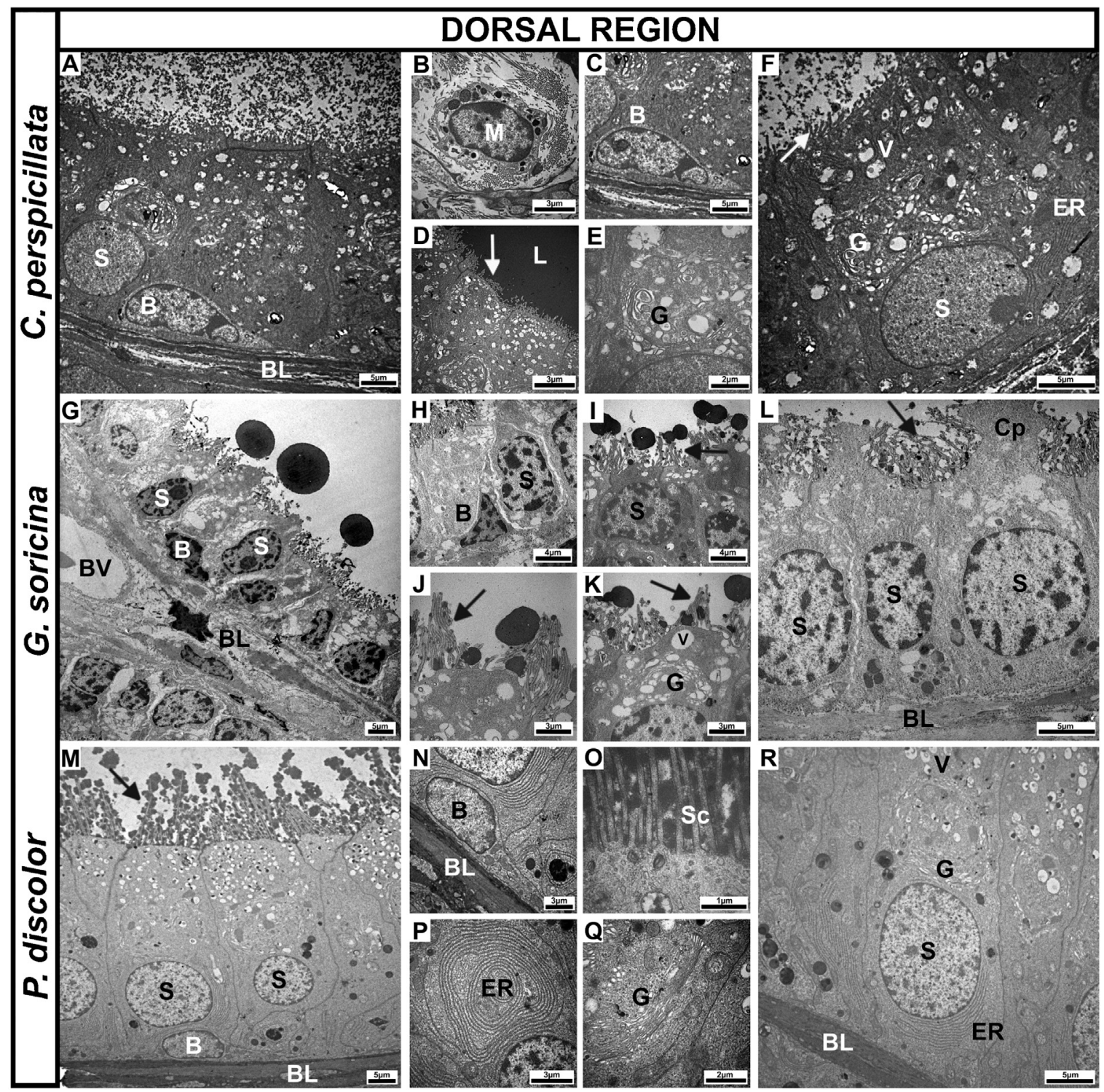

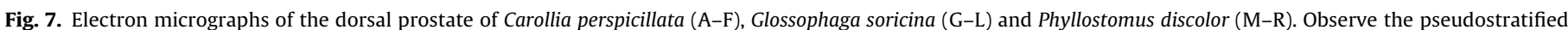

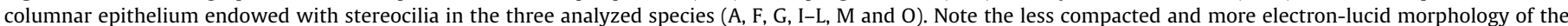

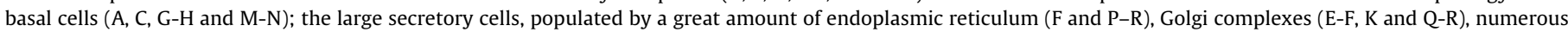

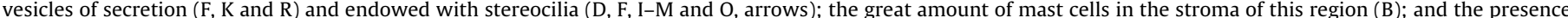

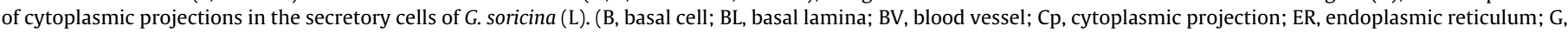
Golgi complex; L, lumen; M, mast cell; S, secretory cell; Sc, stereocilia; V, secretory vesicles).

with elongated and electron-dense nuclei in which the majority of the heterochromatin was associated with the nuclear envelope (Fig. 8C-E and H). Meanwhile, the secretory cells had a columnar morphology containing larger, irregular and basally located nuclei (Fig. 8A-E and G)and a large cytoplasm filled many secretory vesicles (Fig. 8). The secretory vesicles had a crystalloid aspect, with a heterogeneity in composition in C. perspicillata (Fig. 8A-C); a fluid and electro-lucid aspect in G. soricina (Fig. 8D-F); and an electrondense aspect in $P$. discolor (Fig. 8G-I).

Also evident were the presence of stereocilia in the apical portions of the secretory cells of $G$. soricina (Fig. 8F) and the infiltration of blood cells in the epithelium of $P$. discolor (Fig. 8H).

\section{Discussion}

The male reproductive system consists of the external genitalia, the testes, epididymis and ducts and the RAGs. The RAGs includes the prostate, seminal vesicles and the bulbourethral (Cowper's glands) and ampullary glands. The secretions of all these glands are important for supplying macromolecules that contribute to the survival, motility and nutrition of sperm and to protect the male genital tract (Silverthorn, 2010).

Crichton and Krutzsch (2000) postulated that the structure of the secondary male sex organs (RAGs) of bats follows a normal mammalian pattern. Accordingly, the glandular system may or may not be composed of the prostate, seminal vesicles and the bulbourethral and ampullary glands. However, more recent evidences demonstrated that the RAGs of most of the analyzed species are comprise of the prostate (including two or three regions) and the paraurethral and bulbourethral glands with the absence of ampullary glands and seminal vesicles (Puga et al., 2013; Negrin et al., 2014; Christante et al., 2015; Martins et al., 2015; Beguelini et al.,2016). The studies also demonstrated that the prostatic complex varies significantly in morphology, histology and physiology 


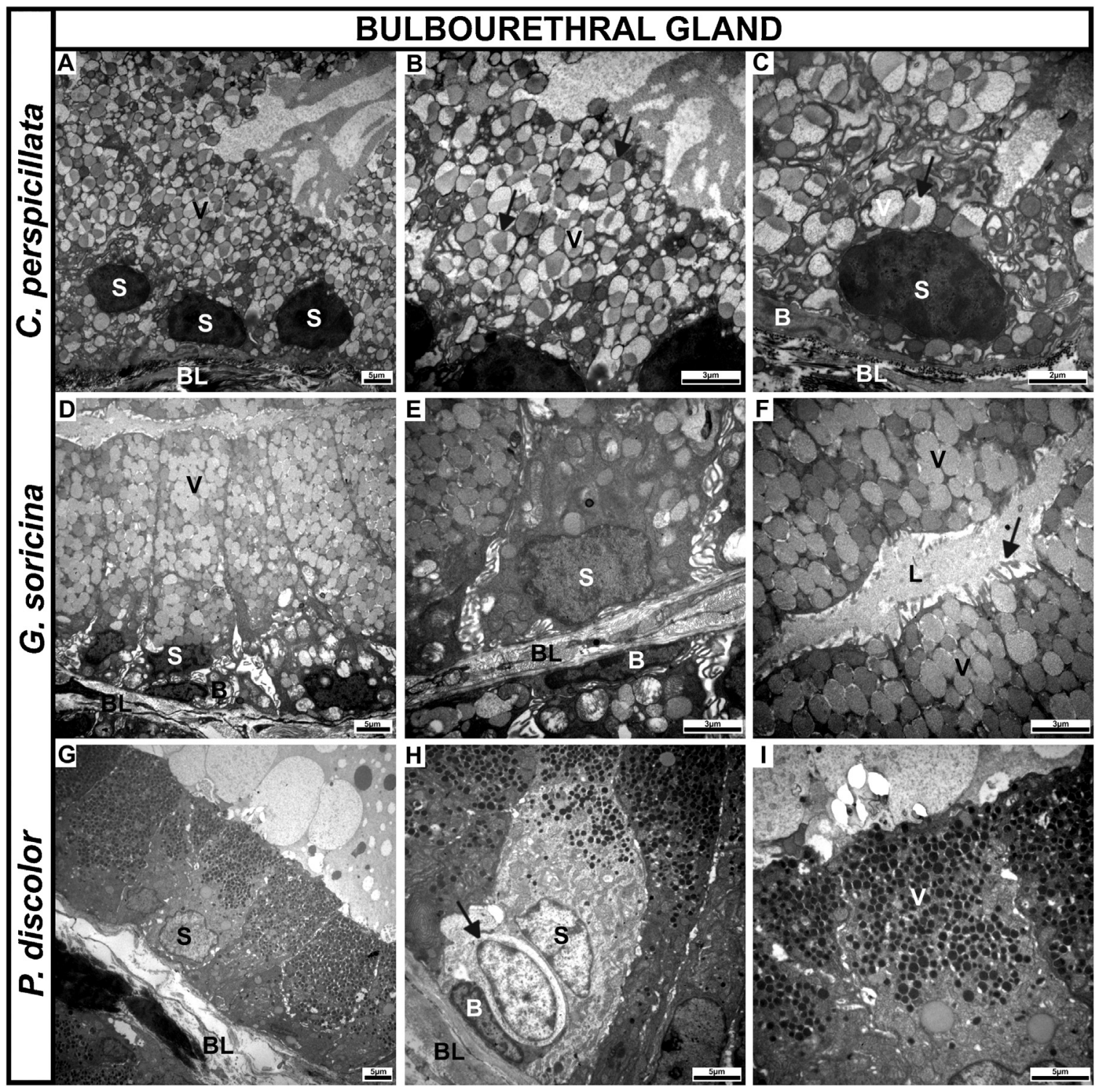

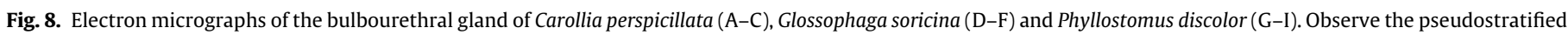

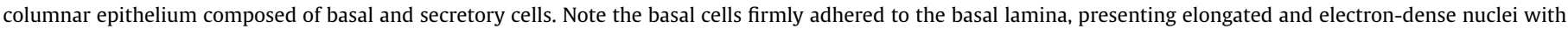

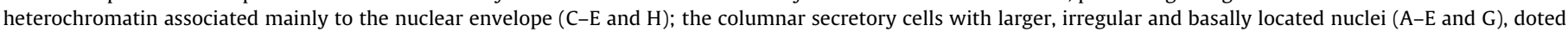

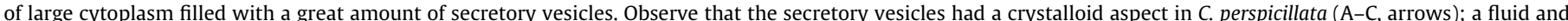

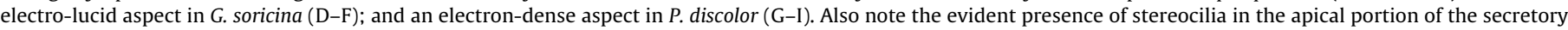

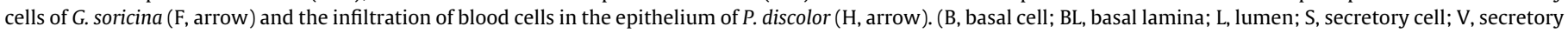
vesicles).

among the different families of bats (Puga et al., 2013; Negrin et al., 2014; Christante et al., 2015; Martins et al., 2015; Beguelini et al., 2015; Beguelini et al., 2016).

Similarly, Martins et al. (2015) demonstrated that the prostatic complex of bats could also vary within the same family. They showed that in the Phyllostomidae family, the prostate complex is divided into two regions (ventral and dorsal) in the Desmodontinae and Stenodermatinae subfamilies and into three regions (ventral, dorsolateral and dorsal) in the Carollinae, Glossophaginae and Phyllostominae subfamilies. The authors also demonstrated variations in size and morphology between the same prostatic regions of different species. Despite these features, there were few detailed studies addressing features of histology, ultrastructure and hormonal control in the RAGs of bats.

In the present study, we verified that the prostatic ventral region did not vary between the three species analyzed. This region pre- sented an undefined epithelium, composed of basal and secretory cells, containing a holocrine PAS-positive secretion. This pattern was also reported for the ventral region of other bat species (Puga et al., 2013; Negrin et al., 2014; Christante et al., 2015; Martins et al., 2015; Beguelini et al., 2016). This suggested that the ventral region was highly conserved in bats and, consequently, that its secretions have a similar importance and physiological function in these species.

Although the composition or the functions of ventral region were unknown, the holocrine nature of its epithelium was well characterized and documented (Puga et al., 2013; Negrin et al., 2014; Christante et al., 2015; Martins et al., 2015; Beguelini et al., 2015; Beguelini et al., 2016). The secretory cells produce a significant amount of secretion, which is stored in secretory vesicles in the cytoplasm for a period, possibly to allow for the activation/maturation of the secretion. After maturation, the cells enter 
into apoptosis, begin to loosen from the basal lamina and to release pieces of cytoplasm, containing many secretory vesicles into the lumen. Puga et al. (2014) demonstrated that this process varies seasonally in the flat-faced fruit-eating bat Artibeus planirostris. In this bat, secretory release is accentuated during the spring and correlates with a significant increase in the number of apoptotic cells (up to $60 \%$ ). Furthermore, this activity was stimulated by variations in testosterone levels and occurred as a preparation to the summer breeding period.

The dorsolateral region of $C$. perspicillata and $P$. discolor showed a pseudostratified cubic morphology, while that from $G$. soricina had a columnar morphology. Although this difference may be due to an intrinsic characteristic of each species, studies have demonstrated that seasonal variations in the height of the prostatic epithelium are common in bats and are generally stimulated by changes in serum testosterone levels, which change during the different phases of the reproductive cycle (pre-mating, copulation, post-copulation, etc.) (Negrin et al., 2014; Puga et al., 2014; Beguelini et al., 2015; Christante et al., 2015). Thus, this difference may be related to differences in the reproductive cycles of each of the analyzed species. However, the large rounded cytoplasmic projections (covered by a significant number of stereocilia) observed in the apical portions of the secretory cells of $G$. soricina may be a species-specific characteristic. The round projections are possibly linked to a process of optimization/increase in the production of secretion, as indicated by the associated large extent of endoplasmic reticulum, Golgi complexes and secretory vesicles.

The dorsal region of the three analyzed species had a pseudostratified columnar epithelium endowed with stereocilia; however, as in the dorsolateral region, the dorsal region of G. soricina also presented the large rounded cytoplasmic projections in the apical portions of the secretory cells. Apical projections filled with endoplasmic reticulum and secretory vesicles, similar to those present in the dorsolateral and dorsal regions of $G$. soricina, were also observed in the dorsal prostatic region of Mongolian gerbils (Rochel et al., 2007).

A comparison of the dorsolateral and dorsal regions revealed some of their morphological similarities. However, the presence/absence of stereocilia and the type of secretion (PAS-positive or negative) markedly differentiate these two regions, demonstrating that they are not the same structure.

The presence of three prostatic regions in the analyzed species markedly differentiate them from the other species of the Phyllostomidae family (Puga et al., 2013, 2014; Martins et al., 2015), which contain only two regions. Negrin et al. (2014) demonstrated that Myotis nigricans (Vespertilionidae) also contain a prostatic complex composed of three regions (ventral, dorsolateral and dorsal); however, they showed the presence of stereocilia at the apex of the secretory cells in the dorsolateral region and their absence in the dorsal region, a result contrary to that observed in the present study.

The histology and ultrastructure of the dorsolateral region of the analyzed species is very similar to the ventral prostate of rodents (Rochel et al., 2007) and that of the dorsal region is very similar to the dorsal prostate of rodents (Rochel et al., 2007). However, the morphology and holocrine pattern of the ventral region does not resemble any of the prostatic lobes of Mongolian gerbil (Rochel et al., 2007) or any of the three different areas of the human prostate (Junqueira and Carneiro, 2008).

The prostatic stroma of the three analyzed species is a protein scaffold mainly composed of reticular and collagen fibers, which forms structures that act as a support network. There were no changes in the disposition of these fibers between the three species analyzed. Similarly, there were no significant species-specific differences in chromatin patterns.
The bulbourethral glands are involved in the lubrication and immune defense of the genital tract, thus playing an important role in fertility by secreting many glycoproteins, including the Prostate Specific Antigen (PSA) (Pedron et al., 1997). In general, the mammalian bulbourethral glands are small and located near the urethra. However, in the three bat species analyzed, these glands are extraabdominally situated on the side of the root of the penis.

Studies published by Crichton and Krutzsch (2000) proposed that these glands contained acini lined by a simple columnar epithelium. However, the histological and ultrastructural analysis of this gland showed, in the three analyzed species, that their acini were composed of a pseudostratified columnar epithelium, composed of basal and secretory cells, with the latter producing a significant amount of PAS-positive secretion. This result was similar to that found in other species of bats (Puga et al., 2013; Negrin et al., 2014).

Moreover, the ultrastructural analysis showed morphological differences in the contents of the secretory vesicles, including a crystalloid aspect in $C$. perspicillata, a homogeneous and electronlucid aspect in G. soricina and a homogeneous and electron-dense aspect in $P$. discolor. This difference in texture and density of secretion can be correlated to differences in the species-specific composition of the secretion.

\section{Conclusion}

In this study the RAGs of three species of phyllostomid bats were morphologically and ultrastructurally characterized, demonstrating the presence of a third prostatic region that has never previously been documented for species of this family. The results also showed the absence of the seminal vesicles and ampullary glands, and better characterized the holocrine pattern of the prostatic ventral region, which is unique to bats.

\section{Author contributions}

Fabiane F. Martins was the principal investigator who acquired and analyzed data; Mateus R. Beguelini contributes to all data analysis/interpretation and to the draft version and development of the manuscript; Cintia C.I. Puga, Eliana Morielle-Versute, Patricia S.L. Vilamaior and Sebastião R. Taboga critically revised the manuscript and approved the article.

\section{Acknowledgements}

We thank Luiz Roberto Falleiros Junior for technical help. We gratefully acknowledged the scholarships awarded to Fabiane Ferreira Martins, Cíntia Cristina Isicawa Puga and Mateus Rodrigues Beguelini by the São Paulo State Research Foundation (FAPESP, Processes: 2010/03128-0, 2011/01323-2 and 2012/09194-0, respectively). Financial support from Grants 2009/16181-9 and 2009/03470-2 from the São Paulo State Research Foundation (FAPESP) and the Brazilian National Research and Development Council (CNPq) Processes: 300163/2008-8 and 301596/2011-5 research fellowships to SRT and Process: 302008/2010-1 to EMV, are gratefully acknowledged.

\section{References}

Alvarez, J., Willig, M.R., Jones, J.K., Webster, D., 1991. Glossophaga soricina. Mamm. Species 379, 1-7

Beguelini, M.R., Puga, C.C.I., Taboga, S.R., Morielle-Versute, E., 2013a. Annual reproductive cycle of males of the flat-faced fruit-eating bat, Artibeus planirostris (Chiroptera: Phyllostomidae). Gen. Comp. Endocrinol. 185, 80-89.

Beguelini, M.R., Taboga, S.R., Morielle-Versute, E., 2013b. Ultrastructural characteristics of the spermatogenesis during the four phases of the annual reproductive cycle of the black Myotis bat, Myotis nigricans (Chiroptera: Vespertilionidae). Microsc. Res. Tech. 76, 1035-1049. 
Beguelini, M.R., Falleiros, L.R., Góes, R.M., Rahal, P., Morielle-Versute, E., Taboga, S.R., 2014a. Differential expression of aromatase, estrogen receptor alpha and $17 \beta-H S D$ associated with the processes of total testicular regression and recrudescence in the bat Myotis nigricans (Chiroptera: Vespertilionidae). Gen. Comp. Endocrinol. 201, 53-64.

Beguelini, M.R., Góes, R.M., Rahal, P., Taboga, S.R., Morielle-Versute, E., 2014b. Two periods of total testicular regression are peculiar events of the annual reproductive cycle of the black Myotis bat, Myotis nigricans (Chiroptera: Vespertilionidae). Reprod. Fertil. Dev. 26, 834-846.

Beguelini, M.R., Góes, R.M., Rahal, P., Morielle-Versute, E., Taboga, S.R., 2015. Impact of the processes of testicular regression and recrudescence in the prostatic complex of the bat Myotis nigricans (Chiroptera: Vespertilionidae). J. Morphol. 276, 721-732.

Beguelini, M.R., Puga, C.C.I., Morielle-Versute, E., Taboga, S.R., 2016. Comparative analysis of the male reproductive accessory glands of bats Noctilio albiventris (Noctilionidae) and Rhynchonycteris naso (Emballonuridae). J. Morphol. (in press).

Behmer, O.A., Tolosa, E.M.C., Freitas-Neto, A.G., 1976. Manual de Técnicas para Histologia Normal e Patológica. Editora da Universidade de São Paulo, São Paulo (239 p.).

Christante, C.M., Beguelini, M.R., Puga, C.C.I., Morielle-Versute, E., Vilamaior, P.S.L Taboga, S.R., 2015. Structure, histochemistry and seasonal variations of the male reproductive accessory glands in the Pallas's mastiff bat, Molossus molossus (Chiroptera: Molossidae). Reprod. Fertil. Dev. 27, 313-322, http://dx. doi.org/10.1071/rd13232.

Cloutier, D., Thomas, D.W., 1992. Carollia perspicillata. Mamm. Species 417, 1-9.

Crichton, E.G., Krutzsch, P.H., 2000. Reproductive Biology of Bats. Academic Press, London.

De Knegt, L.V., Silva, J.A., Moreira, E.C., Sales, G.L., 2005. Morcegos capturados no município de Belo Horizonte, 1999-2003. Arq. Bras. Med. Vet. Zootec. 57, 576-583.

Gömöri, G., 1937. Silver impregnation for reticulin in paraffin sections. Am. J. Pathol. 13, 993-1002.

Jesik, C.J., Holland, J.M., Lee, C., 1982. An anatomic and histologic study of the rat prostate. Prostate 3, 81-97, http://dx.doi.org/10.1002/PROS.2990030111.

Junqueira, L.M., Carneiro, J., 2008. Histologia básica, 11th ed. Guanabara Koogan, Rio de Janeiro, pp. 426-427.

Krutzsch, P.H., Nellis, D.W., 2006. Reproductive anatomy and cyclicity of the male Brachyphylla cavernarum (Chiroptera: Phyllostomidae). Acta Chiropterol. 8 (2), 497-507.

Krutzsch, P.H., Watson, R.H., Lox, C.D., 1976. Reproductive biology of the male leaf-nosed bat, Macrotus waterhousii in Southwestern United States. Anat. Rec. 184, 611-635.

Krutzsch, P.H., 2000. Anatomy, physiology and cyclicity of the male reproductive tract. In: Crichton, E.G., Krutzsch, P.H. (Eds.), Reproductive Biology of Bats. Academic Press, New York, pp. 92-155.
Kwiecinski, G.G., 2006. Phyllostomus discolor. Mamm. Species 801,1-11.

Martins, F.F., Puga, C.C.I., Beguelini, M.R., Morielle-Versute, E., Vilamaior, P.S.L., Taboga, S.R., 2015. Comparative analysis of the male reproductive accessory glands of bat species from the five Brazilian subfamilies of the family Phyllostomidae (Chiroptera). J. Morphol. 276, 470-480.

McNeal, J.E., 1981. The zonal anatomy of the prostate. Prostate 2, 35-49.

McNeal, J.E., 1983. The prostate gland: morphology and pathobiology. Monogr Urol. 4, 3-37.

Mokkapati, S., Dominic, C.J., 1976. Sites of production of fructose and citric acid in the accessory reproductive glands of three species of male chiropterans. Biol. Reprod. 14 (5), 627-629.

Negrin, A.C., Beguelini, M.R., Puga, C.C.I., Morielle-Versute, E., Vilamaior, P.S.L., Taboga, S.R., 2014. Structure, histochemistry, ultrastructure and seasonal variations of the male reproductive accessory glands in the black Myotis bat, Myotis nigricans (Chiroptera: Vespertilionidae). Reprod. Fertil. Dev. 26, 1188-1197, http://dx.doi.org/10.1071/rd13217.

Pedron, P., Traxer, O., Haab, F., et al., 1997. Cowper's gland: anatomic, physiological and pathological aspects. Prog. Urol. 7 (4), 563-569.

Price, D., 1963. Comparative aspects of development and structure in the prostate. Natl. Cancer Inst. Monogr. 12, 1-27.

Puga, C.C.I., Beguelini, M.R., Negrin, A.C., Morielle-Versute, E., Vilamaior, P.S.L., Taboga, S.R., 2013. Structure, histochemistry and ultrastructure of the male reproductive accessory glands in the Neotropical flat-faced fruit-eating bat Artibeus planirostris (Chiroptera: Phyllostomidae). Reprod. Fertil. Dev. 25 (3), 558-569.

Puga, C.C.I., Beguelini, M.R., Martins, F.F., Morielle-Versute, E., Vilamaior, P.S.L., Taboga, S.R., 2014. Seasonal changes in the prostatic complex of Artibeus planirostris (Chiroptera: Phyllostomidae). Gen. Comp. Endocrinol. 197, 33-42.

Ribeiro, M.G., Lima, S.R., 2000. Iniciação às técnicas de preparação de material para o estudo e pesquisa em morfologia. SEGRAC-Editora e Gráfica Limitada, Belo Horizonte.

Rochel, S.S., Bruni-Cardoso, A., Taboga, S.R., Vilamaior, P.S.L., Góes, R.M., 2007. lobe identity in the mongolian gerbil prostatic complex: a new rodent model for prostate study. Anat. Rec. 290, 1233-1247.

Silverthorn, D.U., 2010. Fisiologia Humana: Uma Abordagem Integrada, 5th ed. Artmed, Porto Alegre (843 p.).

Stevens, A., Lowe, J., 2001. Histologia Humana, 2nd ed. Manole, São Paulo, pp. $131-132$.

Williams, C.F., 1986. Social organization of the bat, Carollia perspicillata (Chiroptera Phyllostomatidae). Ethology 71, 265-282.

Willig, M.R., 1985. Reproductive patterns of bats from Caatingas and Cerrado biomes in Northeast Brazil. J. Mamm. 66, 668-681. 